\title{
What Roman Paradigm for the Dutch Republic? Baroque Tragedies and Ambiguities Concerning Dominium and Torture
}

\author{
Frans-Willem Korsten
}

In 1641 Jan Vos (ca. 1610-1667) wrote and produced his successful play Aran en Titus of Wraak en weerwraak: treurspel (Aran and Titus: Revenge and Revenge in Response: Tragedy). It was a play that has been read and received by many in the nineteenth and twentieth centuries as a serious tragedy, although most scholars, at some point, will admit that the play is spectacular and at times strangely farcical. In the light of the play's being serious, even as a spectacle, the regular scholarly approach to it is that it is didactic in nature. ${ }^{1}$ Still, it was a play that, were it produced in our times, could have been a mixture of slasher movie and screwball comedy, with more than a touch of camp. ${ }^{2}$ It is surely possible that those who had seen Aran en Titus turned home seriously pondered how dangerous it is not to restrain your passions. Probably much more members of the audience returned home having fully enjoyed the spectacle and the horror, with a couple of good thrills, many good laughs and some moments of the sublime. Or, if they were pondering, they may have been considering the play's reflection on the extreme violence in classical imperial Rome.

The text of the play is dedicated to Caspar Barlaeus (1584-1648), the distinguished scholar of the Amsterdam Athenaeum Illustre, who was so kind to present Vos with a praise poem that ends as follows:

\footnotetext{
1 A paradigmatic case is a passage from the national site on Dutch literary history (www .literatuurgeschiedenis.nl): 'Passion and violence were the regular ingredients with Vos, not because he enjoyed them so much but to show that it is dangerous to lose your self-restraint' ('Emotie en geweld waren vaste ingrediënten bij Vos, niet omdat hij daar zo van genoot maar om aan te tonen dat het gevaarlijk was om je zelfbeheersing te verliezen.' <http://www .literatuurgeschiedenis.nl/lg/goudeneeuw/literatuurgeschiedenis/lggeo16.html>).

2 Were it to be performed it could be much like Zoé Ford's Titus Andronicus in 2013, with an audience that resembled the jeering audience of Shakespeare's time; for a response to this 'fringe production' of a play that is described as a 'gore-fest' see for instance http://www .standard.co.uk/goingout/theatre/titus-andronicus-arcola-theatre-review-8878513.html.
} 
Hier strijt de Kaizers kroon met d'ongetoomde min. Hier kijft de oorlooghsmond met 't geestlijk hofgezin. Ik stae gelijk bedwelmt en overstolpt van geest.

De schouburg wort verzet, en schoeyt op hooger leest. Rijst Sophocles weêr op? stampt Aeschylus weêr hier? Of maekt Euripides dit ongewoon getier?

Neen. 't is een Ambachtsman, een ongelettert gast, Die nu de gantsche rey van Helicon verrast.

Die noyt gezeten heeft aen Grieks of Roomsche disch, Wijst nu de weerelt aen, wat dat een Treurspel is. Athenen las het Spel, en sprak: ik schrijf niet meer; Die ons door glas verlicht, verduystert al ons eer.

(Here the imperial crown battles with unrestrained love Here, the mouth of war barks at the spirited court family. I remain as if mesmerized, my spirit overtaken; The theater is being altered, its shoe put on a higher last Is Sophocles re-rising? Aeschylus walking amongst us?

Or is Euripides making this unusual thunder?

No. It is a craftsman, an illiterate guest

Who now surprises the entire set of Muses

Who never sat at a Greek or Roman dish And now points out to the world what a tragedy is. Athens read the Play and spoke; I'll write no more, Who enlightens us by glass, puts all our honor in the shade. $)^{3}$

The last line is a pun on Vos's business as a glass-maker (also the theme for a praise poem by Constantijn Huygens), that emphasizes the man's status as a craftsman. This is already hinted at earlier by the pun on the proverb of the shoemaker and his last. It is made explicit a few lines later when Vos is first and foremost sketched as a 'craftsman' ('Ambachtsman'). This shoemaker did not stick to his last, though, he aimed higher. He might even be equal to the greatest classical Greek authors. A reader/author whose distinction is evidenced by his name, 'Of Athens' ('Athenen'), has given up hope to ever write something better than what the glass-maker has produced here. The humble and at the same time almost hyperbolic status of the author is indicated the more, finally, by the fact that someone who has never had knowledge of either Greek or Roman

3 Jan Vos, Alle de gedichten van den Poëet Jan Vos. Jacob Lescailje, Amsterdam 1662, p. 8. 
'dishes', who is an illiterate with no knowledge of the three great Greek tragedy writers, is not only 'altering' the theater but also showing us what tragedy really is.

My point is not so much whether Barlaeus's praise is to be taken seriously, although such an assessment would have consequences for the serious or not so serious nature of Vos's 'tragedy'. In what follows I will focus especially on the relation between civil, and in that sense, humble Amsterdam and imperial Rome in taking my cue especially from the play's abundant display of extreme violence, and torture. The latter was at the heart of a pivotal and principal reflection in the Dutch Republic; a reflection in which an intrinsic relation was brought forward between imperial rule and torture. In this context my question is not if we can consider Vos's play as farcical per se but as a civil reflection on the perversity of power. To answer the question I will need a rather long detour.

\section{Torture and Dominium—Johannes Grevius}

The intrinsic relation between torture and imperial rule was brought forward by Johannes Grevius (1584-1622) who had escaped the Amsterdam 'tuchthuis', the house of correction, punishment or discipline, in October 1621, after a failed attempt to escape in August of the same year. ${ }^{4}$ Grevius, like his rescuer Dominicus Sapma, had been imprisoned in Amsterdam for his Remonstrant or Arminian preaching in the Republic, in the dire years after the Synod of Dordt from 1618. Counter-Remonstrant parties, strongly supported by Stadholder Maurits, attempted to clear the Republic of what they considered to be the religiously impure, and their zeal knew few restraints. Many people were intimidated, harassed, arrested, blackmailed, or banned, and a considerable number were threatened with the rack. Some were tortured severely; others were executed or at least imprisoned and threatened with circumstances that came close to torture. In this particular case, Grevius especially

4 The story of this escape reads like a novel, also because its featuring cast consists of a visiting wife, Grietje Ulbes, who helped to free her husband, the convicted Remonstrant minister, Dominicus Sapma, together with Samuel de Prince and Grevius. More on Sapma and his process can be found in J.G. van Dillen, 'Documenten betreffende de politieke en kerkelijke twisten te Amsterdam (1614-1630)', Bijdragen en Mededeelingen van het Historisch Genootschap, 59 (Utrecht: Kemink \& Zoon, 1938), pp. 200-203. For an at times hilarious and detailed report of the respective escapes, see Jan Wagenaar, Amsterdam, in zijne opkomst, aanwas, geschiedenissen, voorregten, koophandel, [etc.] (Amsterdam: Isaac Tirion, 176o), pp. 478480 . 
had been dealt with harshly. The result, however, was one of Europe's first elaborate treatises against the use of torture, Grevius's Tribunal reformatum from $1624 . .^{5}$

Grevius had been denied access to all sorts of literature in prison. He was allowed, however, to study law, especially Roman law, and this had brought him to the heart of a matter that was both personally and politically vexing; personally because he had been tortured, and politically because torture to him was the inevitable outcome of a distinct way of organizing the political domain, namely on the basis of some sort of household, or dominium. In his treatise Grevius stated that the relation between torture and slavery had been intrinsic in classical Rome, precisely in relation to the model of the dominium, or household. ${ }^{6}$ The two combined should be rejected in principle since Christians, being free, could not tolerate torture any more than slavery, so Grevius argued. This brought in an ambiguity, however, which will be central to my argument. Studying Roman law had brought Grevius to respect it, but at the same time the coincidence of dominium, slavery and torture formed part and parcel of the Roman heritage, also in terms of Roman law. Such an ambiguity with regard to the Roman paradigm was not idiosyncratic. It defined attitudes towards the Roman paradigm more in general in the Dutch Republic, just as it did, in different ways, in England.

In its political and legal focus on torture, Grevius's argument was partly unique. In the previous century protests against torture had focused mainly on the fact that it was used for the wrong purposes, in relation to witchcraft. ${ }^{7}$ Grevius now related the item of torture to a distinct political model. In relation to this problem the theme of slavery was not unique at all however. It was part of a broader Western-European reconsideration of the Roman heritage with regard to the issue of political freedom and slavery or servitude. In this context Grevius's argument corresponded with Jean Bodin's argument on the issue in

5 Johannes Grevius, Tribunal reformatum in quo sanioris et tutioris iustitiae via iudici christiano in processu criminali commonstratur, reiecta et fugata tortura. Typis \& impensis Henr. Carstens, 1624. I will be quoting from the 1737 edition with the same title, published at: Gvelpherbiti, sumptibus I.C. Meisneri, 1737. Early studies on Grevius are Johannes Janssen, History of the German People After the Close of the Middle Ages, transl. A.M. Christie, Vol. 16 (London: Kegan Paul, 1910); and Alec Mellor, Un chefd'oeuvre méconnu: Le 'Tribunal reformatum' de Grevius (1624) (Paris: Sirey, 1949).

6 Grevius, Tribunal, Lib. 1, caput II, par. VI, VII, VIII, pp. 23-29.

7 On this, see Helen Parish (ed.), Superstition and Magic in Early Modern Europe: A Reader (London and New York: Bloomsburt, 2015), especially Brian P. Levack's chapter 'The Decline and End of Witchcraft Prosecutions', pp. 336-372. 
the first book (chapter v) of his six volume study on the state and sovereignty from 1576: Les six livres de la République (Six Books of the Commonwealth). ${ }^{8}$ Here Bodin had argued, much like Grevius fifty years later, that slavery had led to cruelties that were, politically and juridically speaking, unacceptable. However, whereas Bodin diligently wanted to keep despotic rule apart from paternal rule in order to be able to propagate the patriarchal rule of the sovereign, Grevius criticized the 'original' conflation of torture and slavery as the intrinsic effect of the conflation of the Roman dominium with political rule. The far reaching consequences for the conceptualization of politics in relation to a dominium, or a 'house' with a master or, more specifically, a father, was one of the hottest points of debate in the seventeenth century. The history of slavery per se, this is to say, had a connection from the start with political slavery, as when the free subjects of some sort of political entity were not really free at all but subjected to the rule of a master who could rule at will. ${ }^{9}$ Mary Nyquist considered this 'Greco-Roman polarity between free and enslaved' to be at the basis of massive discussions in Europe in the sixteenth and especially seventeenth century, especially because, by then, the issue had become even more complicated with the arrival of trans-Atlantic slave trade (to which, for reasons of brevity, I will not be paying attention here). ${ }^{10}$

The responses to the polarities in play in the Dutch Republic were both similar to and different from the ones in England, where, as Quentin Skinner has shown, the slavery issue was mainly dealt within the context of authors propagating the republican freedom of citizens. At the same time, however, especially in the case of Thomas Hobbes, the notions of slave and slavery would be softened into those of servant and servitude, and then be a paradigm for political obedience, or subjection, which was the price to be paid for a sovereign who was the safeguard against radical disorder. ${ }^{11}$ In this context Skinner argued that

Jean Bodin, The Six Bookes of a Commonweale, transl. Richard Knolles, ed. Kenneth Douglas McRae (Cambridge: Harvard University Press, 1962).

On this see, for instance, Quentin Skinner, 'John Milton and the politics of slavery', in id., Visions of Politics: Renaissance Virtues (Cambridge: Cambridge University Press, 2002), pp. 286-307, or 'Rethinking Political Liberty', History Workshop Journal 61 (2006), 156-170. Interestingly, in both cases, or throughout the work of Skinner, the issue of torture and its connection to the logic of the household as a paradigmatic political model, is not dealt with.

Mary Nyquist, Arbitrary Rule: Slavery, Tyranny and the Power of Life and Death (Chicago: Chicago University Press, 2013), p. 72.

11 On the two different ways of dealing with the issues of slavery and freedom on the one hand and servitude and subjection on the other, see Quentin Skinner, 'On the Liberty of 
'one of the deepest divisions in modern European thought' was the division between 'the neo-Roman theory of freedom and self-government, $[\ldots]$ and the modern theory of the state as the bearer of uncontrollable sovereignty'. ${ }^{12}$ Yet he could only state this while silently accepting the fact that the Roman propagators of republican freedom were masters of a dominium themselves, with slaves. Moreover, he could only state this by ignoring the fact that Thomas Hobbes was an equally avid reader of Roman texts that allowed him to postulate the 'sameness of dominion and subjection.. ${ }^{13}$ The conceptual conflation of political power with dominium points directly to a Roman origin. It was as 'neo-Roman' as the republican renaissance.

All in all, it must be clear that, in terms of its political and ethical configuration, the Roman heritage was ambiguous per se, since it mixed the tradition of the republican freedom of citizens with the tradition of both slavery and imperial mastery by caesarian rulers, which was translated to the rule of popes who considered themselves in the context of law as the inheritors of imperial rule. This ambiguity specifically bothered the Dutch Republic. Much like those opposing the so-called tyrannical rule of the sovereign in England, the Republic and Amsterdam considered themselves to be the inheritor of Rome's republican liberties and virtues. To the Republic, however, the glory of Rome that had been built up from scratch also provided the paradigm for its own unexpectedly glorious and quasi-imperial status. Yet in this context, Rome's paradigm of imperial rule-one that was perhaps impressive but also turned subjects into politically speaking un-free subjects, or 'slaves' - proved more difficult to swallow, or had to be downright rejected. And again, the political issue easily shifted into a religious one, since Rome had also become shorthand for the Roman Catholic Church, which was regarded by many in the Dutch Republic as a tyrannical power in itself, while it was considered by others, such as Vondel and Grotius, as the only paradigm that could save Europe from sectarian strife and ruin.

In what follows I will trace the ambiguities in play in some baroque authors and tragedies that dealt with the paradigm of Rome in a specifically Dutch way. The question to be answered, in this respect, is how Dutch baroque art dealt with the more difficult or controversial parts of the Roman heritage. Did it consider torture, for instance, to be functional or acceptable, was it fascinated by it, did it indulge in it, or did it principally reject it? And if there were parties,

the Ancients and the Moderns: A Reply to My Critics', Journal of the History of Ideas 73 (2012), 127-146.

12 Quentin Skinner, Visions of Politics, p. 9.

13 Mary Nyquist, Arbitrary Rule, p. 324. 
either political or religious, that wanted to define politics in the Dutch Republic as a matter of dominium, what would be the adequate response?

\section{Foundations of Law: Public Affairs Versus the Master-Father of a House}

A song about the escape of Grevius and De Prince appears on one of the earliest albums in the impressive list of CD's produced under the guidance of Louis Grijp by the Utrecht based company Camerata Trajectina. The album is called Bavianen en Slijkgeuzen (1995), an explicit reference to the most famous study, from 1974, on the violent conflict in daily life between Remonstrants and Counter-Remonstrants by A.Th. van Deursen. Counter-Remonstrants were mocked as 'slijkgeuzen' ('mudbeggars') since 1612, when their meetings had been prohibited in Rotterdam and they were forced to move them outside of town, to places that could be reached through muddy pathways. A little later 'bavianen' or 'baboons' became a popular nickname for Arminians because the two words in Dutch sound similar, and monkeys had been considered devilish since the Middle Ages. ${ }^{14}$ The song performed on the album is called: 'On the salvation of Samuel de Prince and Johannes Grevius' ('Op de verlossinge van Samuel de Prince, ende Johannes Grevius') and it rejoices in the escape of both men from the Amsterdam prison. It considers it an intervention from God, who, from now on, will teach the Counter-Remonstrants to no longer 'tyrannize' the country. In the original: 'het tiranniseeren sal Hy u verleeren ... ${ }^{15}$

The very word 'tyranny' has a considerable background in medieval and classical history and in contemporary debate, but in the Dutch Republic the most direct connotation was the rule of King Philip II. In 1581, the Dutch States General had formulated it as follows, in their so-called 'Plakkaat van Verlatinge', or Act of Abjuration:

De Staten Generael van de geunieerde Nederlanden. Allen dengenen die dese tegenwoordighe sullen sien ofte hooren lesen, saluyt.

Alsoo een yegelick kennelick is, dat een Prince van den lande van Godt gestelt is hooft over zijne ondersaten, om deselve te bewaren ende be-

\footnotetext{
14 A.Th. van Deursen, Bavianen en Slijkgeuzen: Kerk en kerkvolk ten tijde van Maurits en Oldenbarnevelt (Franeker: Van Wijnen, 1998), pp. 320-321.

15 Camerata Trajectina, Bavianen en Slijkgeuzen: Liederen van Remonstranten en ContraRemonstranten uit het begin van de 17de eeuw (Globe 6031, 1995).
} 
schermen van alle ongelijk, overlast ende ghewelt gelijck een herder tot bewaernisse van zijne schapen: En dat d'ondersaten niet en sijn van Godt geschapen tot behoef van den Prince om hem in alles wat hy beveelt, weder het goddelick of ongoddelick, recht of onrecht is, onderdanig te wesen en als slaven te dienen: maer den Prince om d'ondersaten wille, sonder dewelcke hy geen Prince en is, om deselve met recht ende redene te regeeren ende voor te staen ende lief te hebben als een vader zijne kinderen ende een herder zijne schapen, die zijn lijf ende leven set om deselve te bewaren. En so wanneer hy sulx niet en doet, maer in stede van zijne ondersaten te beschermen, deselve soeckt te verdrucken, t'overlasten, heure oude vryheyt, privilegien ende oude herkomen te benemen, ende heur te gebieden ende gebruycken als slaven, moet ghehouden worden niet als Prince, maer als een tyran ende voor sulx nae recht ende redene magh ten minsten van zijne ondersaten ...

(The States General of the United Provinces of the Low Countries, to all whom it may concern, do by these Presents send greeting:

As it is apparent to all that a prince is constituted by God to be ruler of a people, to defend them from oppression and violence as the shepherd his sheep; and whereas God did not create the people slaves to their prince, to obey his commands, whether right or wrong, but rather the prince for the sake of the subjects (without which he could be no prince), to govern them according to equity, to love and support them as a father his children or a shepherd his flock, and even at the hazard of life to defend and preserve them. And when he does not behave thus, but, on the contrary, oppresses them, seeking opportunities to infringe their ancient customs and privileges, exacting from them slavish compliance, then he is no longer a prince, but a tyrant, and the subjects are to consider him in no other view. $)^{16}$

The word 'tyrant' is explicit ('tyran') in the text. This term is intrinsically connected to the behavior of a tyrannical ruler, someone who considers his subjects to be slaves. In contrast and originally, so the Act argues, this is not how

16 I use the translation of the original as it can be found on the Groningen website established by George M. Welling, 'American History: From Revolution to Reconstruction and Beyond': $<$ http://www.let.rug.nl/usa/documents/before-16oo/plakkaat-van-verlatinghe-1581-july -26.php> [accessed 15 August 2014]. 
God conceived of 'people'. Yet although the English translation uses the term 'people,' the original says 'ondersaten' throughout. This term can only be correctly translated as 'subjects'. And even though the translator's choice of 'people' is adequate, it is only in its most general sense because, obviously, God did not create political subjects. He made 'man'. The original text of the 'Plakkaat' is playing with a choice between two distinct options, then. Either God made man, who would later become a political subject but not a slave. Or God made political subjects who were not slaves but clearly child-like and in need of a father-like figure or a shepherd.

If the latter option is seriously considered, man was either not made free, but rather like, indeed, a child in need of princely and fatherly guidance, or if created free, people would choose to become like sheep in order to form a polity. The beginning of the 'Plakkaat' paradoxically mixes two familiar versions of sovereignty, then, that Quentin Skinner saw as 'one of the deepest divisions in modern European political thought': the sovereignty of man and by implication the people, and that of the prince. These two versions had been at the basis of the different conceptualizations of sovereignty by, amongst others, Jean Bodin and Johannes Althusius in the previous century. ${ }^{17}$ In the seventeenth they were followed by figures such as Robert Filmer and Thomas Hobbes on the one hand and John Locke, John Milton and the movement of the Levellers on the other. Whereas Bodin, Filmer and Hobbes argued, in different ways, that the state could be the only and supreme political power, embodied in the prince or the sovereign, Althusius, Locke, Milton and the Levellers would argue that a man's individual right to liberty can never be given away, nor usurped. Basically, and despite Skinner's thesis that this was a modern split, the opposition had troubled the history of European politics from the very beginning. This is at least what Hannah Arendt argued in her analysis of classical Greek political thought with its admiration for despots (and in relation to what follows it is of relevance that the Greek word $\delta \varepsilon \sigma \pi \delta$ tn $\zeta$ meant 'lord of the house' or 'ruler')..

17 On Bodin and Althusius, see Jean de Benoist, 'What is Sovereignty', Telos 116 (Summer 1999), pp. 99-118; <http://www.alaindebenoist.com/pdf/what_is_sovereignty.pdf> [accessed 15 September 2014], translated by Julia Kostova from 'Qu'est-ce que la souveraineté?', Éléments 96 (November 1999), pp. 24-35.

18 Hannah Arendt developed these ideas, for instance, in The Human Condition (Chicago: University of Chicago Press, 1958), pp. 195, 222-223 but also in The Promise of Politics, ed. and introd. by J. Kohn (New York: Schocken Books, 2005) and especially in an article entitled 'The Great Tradition II: Ruling and Being Ruled', Social Research 74:4 (2007), pp. 941-954. See also Keith Breen, 'Law beyond Command?: An Evaluation of Arendt's 
Arendt's analysis finds a strong analogy in the early fourteenth century, when Marsilius of Padua in his Defensor pacis (1324) criticized what he considered to be a wrong turn in European politics under the Roman Catholic Church, a wrong turn that was a result of the fact that the father of an oixos (a household, in this case: the Church) tried to rule public affairs. ${ }^{19}$

In relation to these debates it is important to see that Grevius stated that torture and slavedom were connected in origin because both were defined by the concept of dominium and the master that ruled it:

Ab absoluta illa Dominorum in mancipia sua potestate, primam exstitisse, truculentiae huius orgininem nemini dubium esse poterit, qui ad illud attenderit, totum illum de Quaestionibus in Digestis titulum, nil pene nisi servos crepare, atque non initio statim, hunc, cum torquendi morem aliunde asciscerent Romani, in libera corpora usitatum fuisse. ${ }^{20}$

(No one can doubt that this violence took its first origin from that absolute power of masters towards their slaves, which pertains to the fact that that entire concept of 'Interrogations' [i.e. tortures, FWK] in the Digests, restricts itself to slaves only, and states that is was not immediately from the beginning used against free men, when the Romans took over the habit of torturing from elsewhere. $)^{21}$

Grevius is much ahead of his time here, since his astute assumption conformed to later, nineteenth-century ideas. For instance the great historian and legal scholar Theodor Mommsen argued that 'Roman domestic discipline was the basis of later Roman penal procedure in civil and criminal law'.22 The torture

Understanding of Law', in Marco Goldoni and Christopher McCorkindale (eds.), Hannah Arendt and the Law (Oxford and Portland: Hart publishing, 2012), pp. 15-34.

19 Marsilius of Padua, The Defender of the Peace, ed. and transl. Annabel Brett (Cambridge: Cambridge University Press, 2005) Cambridge Texts in the History of Political Thought. On the history of Western political thought on the issue, see Quentin Skinner, The Foundations of Modern Political Thought: The Renaissance (Cambridge: Cambridge University Press, 1978).

20 Grevius, Tribunal, Lib. 1, cap. II, par. viI.

21 Grevius is referring here to the Justinian Digest in which quaestio is the common name for torture. On free men and slaves, see also, book I, cap. v, 'Human Status'; The Justinian Digest, vol. 1, transl. and ed. Alan Watson (Philadelphia: University of Pennsylvania Press, 1985); I thank Jan Bloemendal and Antje Wessels for the translation of this passage.

22 Edward Peters, Torture (Philadelphia: University of Pennsylvania Press, 1996), p. 19. 
that was codified in Roman law had its origin in forms of criminal law relating to dominium, that is, to early forms of law relating to the master of a house and the ones belonging to that house. Within the confines of his own dominium the master of the house was legally entitled to deal with his property as he saw fit, including his slaves, who were not legal subjects and who could be tortured legitimately to either preserve order, to punish them, or to extract information from them regarding crimes. This right to torture was at first not only preserved for, but also strictly limited to slaves. Torturing free citizens was principally forbidden.

As for slaves, one of the worst crimes was killing the master of the house. In the context of Roman jurisprudence, this became a case analogous to parricide, to killing the father. The slippage from master to father in effect radicalized the nature of the laws in question, and turned the preservation of order into a more symbolically charged issue. When the law regarding juridical matters in a house or household was transplanted to the public domain, as was the case after the Roman Republic had changed into an empire led by an Augustus or Caesar, the consequences were considerable. As R.C. van Caenegem puts it, the key characteristic of the late Roman Empire was that:

[...] its millions of multiracial inhabitants were subjected to one common domination [...]: all public authority had been vested in the emperor or descended from him. This emperor-called dominus since Diocletian (d. 316) — was absolute, i.e. not bound by the law, as he himself was its supreme source. ${ }^{23}$

Legally speaking, public affairs became encapsulated more and more by the framework of the dominium or household. The ruler of public affairs was seen as the master of the house, or, symbolically, its father. As Floyd Lear saw it, in his study Treason in Roman and Germanic Law, the Roman doctrine of treason:

... the crimen laesae maiestatis, the injuring or diminishing of majesty, grew out of early Roman religious sanctions against the killing of a father, parricidium, and the actions of a Roman who becomes an enemy of his own community and aids its enemies, perduellio. ${ }^{24}$

\footnotetext{
23 R.C. van Caenegem, An Historical Introduction to Western Constitutional Law (Cambridge: Cambridge University Press, 1995), p. 34.

24 Floyd Seyward Lear, Treason in Roman and Germanic Law (Austin: University of Texas Press, 1965 [2011]). The quote is from Peters, p. 25.
} 
From the end of the Roman Republic to its imperial reconfiguration it was a relatively short route towards the conflation of people, state and ruler. One who injured maiestas, simultaneously injured the communion, the state and its 'father': the ruler or, in early modern terms, the prince. Consequently, the right to torture someone was extended far beyond the realms of slavedom. Anybody could now be tortured, including free citizens, who found themselves dealing with the logic of a Roman household as soon as matters became tenser politically, because the Roman State had become a familia with the emperor (like before that the consuls) as the pater familias. ${ }^{25}$

It is not hard to see how this almost seamlessly applies to the situation in the seventeenth century, partly due to the fact that Roman law had become the major impulse in the codification of law in the nascent European states. The two odd cases here would be England and the Republic, though for different reasons. What Skinner saw as the resurgence in England of 'the neoRoman theory of freedom and self-government' was developed in a situation where common law prevailed. In the context of the Republic, however, it is of importance to note that Philip I had given the Low Countries its first codified law in 1570 by means of his Criminal ordinance (one that preceded the French Grand ordonnance criminelle from 1670 by a century). Yet its implementation had never been successful. ${ }^{26}$ With the Republic, moreover, the legal system had lost, temporarily, its codifying political centre. Especially in the situation after the Synod of Dordt, in a juridical system that spread out over about a hundred different courts, religious parties infiltrated the judicial system. In this context, it may be repeated that the Roman law against parricide originated in religious sanctions and that in the course of Roman history a conflation took place that was to play an important role in the Counter-Remonstrant policy of the purification of the state. The purification that took place was founded on the idea that the state was a household ruled by a father, in this case either the prince sanctioned by God, or God himself, whose majesty was beyond all other majesties.

The Dutch case stood in contrast, here, with what would happen in England when the Parliamentarians in 1649 would proceed to realize what Van Caenegem called a 'radical clean up' (although veritable legal reform was in the end

25 On this transition and the legal practice at stake, see Jane Pölönen, 'Plebeians and Repression of Crime in the Roman Empire: From Torture of Convicts to Torture of Suspects', in Revue internationale des droits de l'Antiquité 51 (2004), 217-257.

26 See Ludwig von Bar, A History of Continental Criminal Law (Boston: Little, Brown and Company, 1916), pp. 304-306. <https://archive.org/details/historyofcontineoobarl> [accessed 15 September 2014]. 
not successful). In England the Parliamentarians acted against the king's desire for centralization. In the Dutch Republic the opposite was the case. The States were sovereign and there was no high court on the level of the States-General. Cities had rights that could not be infringed by higher courts and had their own courts. In response, especially under Maurits, or his grandson, William II, the impetus was to get to a one-state-one-religion system. ${ }^{27}$

Culturally speaking the similarities and differences between England and the Republic, but also internal contradictions in both countries, could be traced throughout the century, according to Charles-Edouard Levillain, in similar but also different readings of Tacitus - readings that Levillain considered in terms of 'the use and misuse of Roman history for propaganda purposes'. ${ }^{28}$ Next to Machiavellianism, according to Levillain, one could even speak of Tacitism in the context of the Dutch-English debates on republicanism and sovereignty. He notes, for instance, that Grotius had interpreted Tacitus as describing how liberty and monarchy were nigh irreconcilable, which is why Grotius could glorify the Batavians who only accepted kings in name. To the lesser well known scholar Marcus Zuerius Boxhornius, however, Tacitus had described the opposite: how a country or a state that did not want to end up in ruin needed to be ruled by a monarchical power. ${ }^{29}$ Yet such a power in the Netherlands should be wise not to call himself monarch, which is precisely what William III decided to do, although in the English context, of course, William III would become king. Accordingly Tacitus was read in yet another way, here, concerning the way in which monarchical rule as opposed to republican self-government depended on the nature and use of military men, and by consequence, the army.

The 'use and misuse' of a Roman paradigm was characteristic of an entire century, then. In this context, in the attempt to fuse state and religion, the battle between Remonstrants and Counter-Remonstrants about the (relatively) free or principally not free status of man coincided historically and by analogy with the shift from torture being reserved for slaves to torture being applicable principally to all subjects. According to the logic of predestination all subjects were in the hands of the Father to whose house they all belonged, and who could punish as He saw fit. In the years following the Synod of Dordt, there were enough actors who were willing to act as God's instrument in this punishment. Their ideas were not so different, by the way, from those who would argue that

\footnotetext{
27 Van Caenegem, An Historical Introduction to Western Constitutional Law, p. 118.

28 Charles-Edouard Levillain, 'William III's Military and Political Career in Neo-Roman Context 1672-1702', The Historical Journal 48 (2005), 321-350; especially p. 322.

29 Levillain, 'William III's Military and Political Career', p. 331.
} 
the prince or king was the master-father of the political household, such as Robert Filmer in his treatise with the telling title Patriacha or the Natural Powers of Kings, a treatise published in 1680 but written in the twenties and thirties of the seventeenth century (a treatise that gained fame especially because of John Locke's extensive response to it). Filmer's treatise held that the basis of the political organization of the state was the obedience a family owed their father, as was confirmed in the Book of Genesis 1:26-28. ${ }^{30}$ Filmer was just being part here of a broader movement that was defined by Gordon J. Schochet as 'patriarchalism', with which he indicated the conflation of paternal and monarchical power. Although one of its major sources was the Bible, it was also, as may now have become clear, neo-Roman; as neo-Roman, one could argue, as Skinner's 'republicanism.' ${ }^{31}$

Grevius's battle against torture, therefore, was not just a moral battle. When he held that there is not one argument that is tenable in the defense of torture, his attack on torture extended beyond the strictly moral. In fact, the principle rhetorical audience of his treatise was the prince, as the head of state. Having come to the end of his treatise, he proposed that every sentence involving torture should be signed personally by the Christian magistrate. ${ }^{32}$ This came down to saying that torture, in the end, was a legal and political issue and as such connected to a specific form of rule. And indeed it was, legally speaking and in the light of the European political trajectory to redefine affairs of politics as public affairs, as opposed to private ones, based on the (despotic or tyrannical) logic of a household. In the Dutch Republic this long-term European political battle got one of its telling historical moments. It was one that was related highly ambiguously to the Roman paradigm, which was itself, as already indicated, deeply ambiguous because of its mixture of republic and empire, of politics as a public affair and as a matter of dominium.

30 Robert Filmer, Patriarcha and Other Writings, ed. Johann P. Sommerville (Cambridge: Cambridge University Press, 1991, repr. 2000) Cambridge Texts in the History of Political Thought. The text can be found online; <http://www.constitution.org/eng/patriarcha .htm> [accessed 15 August 2014].

31 Gordon J. Schochet, Patriarchalism and Political Thought: The Authoritarian Family and Political Speculation and Attitudes Especially in Seventeenth-Century England (New York: Basic Books, 1975). 


\section{Ambiguous Allegories: Roman Paradigm, Republican Amsterdam and the Republic's Batavianism}

The new theater that was being built in Amsterdam in the thirties was welcomed by Joost van den Vondel who praised its architect Jacob van Campen as follows: 'We imitate majestical Rome on a smaller scale | now that Kampen is busy building it' ('Wij bootsen 't groote Rome na in 't kleen | Nu Kampen bezig is met bouwen'). ${ }^{33}$ Indeed, at one point, a few years earlier, an important group of humanists had started thinking of a public 'gathering place' built 'according to the way of the old Roman theaters' ('verzamelplaats' [...] 'te bouwen naar de wijze der oude Roomse schouwplaatsen'). In this context, as Ben Albach correctly noted, their ideas were radically different from the ideas about the theaters that were being construed in semblance of the Royal courts. ${ }^{34}$ Yet this Amsterdam theater was not the only building referring back explicitly to republican Rome. The new Amsterdam City Hall, opened seventeen years later, was an even more iconic example.

The Amsterdam City Hall was defined as the eighth miracle of the world by Constantijn Huygens, who addressed the burgomasters of the city as 'Enlightened founders of the world's eighth wonder $\mid$ of so many stones up high, and so many wood down under' ('Doorluchte stichteren van's wereld achtste wonder, | van soo veel steens omhoogh, op soo veel Houts van onder'). ${ }^{35}$ It is a building that appears from the outside and in its structure to be distinctly classical, only to reveal its baroque inside. ${ }^{36}$ Of this City Hall Joost van den Vondel sang the praises and he literally helped fill it in by suggesting topics for its many

33 Joost van den Vondel, 'Op den nieuwen Schouwburgh. Aen den Raedsheer Nikolaes van Kampen', 1637. Joost van den Vondel, Gysbreght van Aemstel, met inleidingen en aantekeningen door Mieke B. Smits-Veldt (Amsterdam: Amsterdam University Press, 1994), p. 34; <http://www.dbnl.org/tekst/vondoo1gysbo1_01/vondoo1gysbo1_01_0016.php> [accessed 15 August 2014].

34 Ben Albach, 'De schouwburg van Jacob van Campen', Oud Holland, 85 (1970), 85-109. The quote has its source in O. Dapper, Historische beschrijvingh der Stadt Amsterdam (Amsterdam, 1663).

35 Constantijn Huygens, Gedichten, deel 6: 1656-1661, ed. J.A. Worp, (Groningen: Wolters, 1896), p. 108; http://www.dbnl.org/tekst/huygooijaw014_01/huygoo1jaw014_01_0004.php.

$3^{6}$ For the simultaneous manifestation of classicism and baroque in Dutch works of art, see Ebeltje Hartkamp-Jonxis, 'Mannerist, Baroque, and Classicist: Narrative Tapestries and Related Paintings in Late Sixteenth- and Seventeenth-Century Holland', in Thomas P. Campbell and Elizabeth A.H. Cleland (eds.), Tapestry in the Baroque: New Aspects of Production and Patronage (New York: The Metropolitan Museum of Art, 2010), pp. 134- 
wall decorations and paintings, and by providing it with several epigrams. To be sure, the City Hall functioned in a deeply religious environment. Yet as the political centre of a new world power, it was highly worldly at the same time, and consequently it was looking not just for historical comparisons but also for historical paradigms that could help define its role in history. The plan for this 'Palace of the Republic' drew from the biblical origin of architecture, but in the seventeenth century eye this was allegorically translated via Rome. On an allegorical level, that is, Rome provided the paradigm. As already indicated, this legacy remained ambiguous. ${ }^{37}$

In a praise poem that was made for the opening of the new City Hall, but also in order to defend the costly building against its many critics, Vondel was explicit about the paradigmatic relation between Rome and Amsterdam, as, for instance, in a passage such as this one:

De Koning van de Stadt, wiens kruin 't gewelt zou tergen

Verkoos Tarpeius bergh alleen, uit zeven bergen,

Omtrent den Tiberstroom, en zijne waterkolck,

Om daer den adelaer en stoel van 't strijtbre volck,

Als op den vryburgh van 't Gemeene best, te planten,

Dat tegens al de maght der weerelt zich zou kanten.

Dus rees het Kapitool, op dezen steenen bult,

Van Romulus met riet gedeckt, en na vergult

Gelijck een gouden bergh, om, in het onderdaelen

En opstaen van de zon, de zon ten trots te praelen

Een eer, waer voor de bergh den vader Numa danckt,

Zoo lang 't Romainsch gebiet, dat nimmer zackt, noch schranckt,

Maer op zijn wyze duurt, de weerelt zal verduuren.

'Inwydinge' vss. $145^{-157}$

153. For a transparent oversight of the uses of the term baroque, see Michel Conan, 'Introduction: The New Horizons of Baroque Garden Cultures', in id. (ed.), Baroque Garden Cultures: Emulation, Sublimation, Subversion (Cambridge mA: Harvard University Press, 2005) Dumbarton Oaks Colloquium on the History of Landscape Architecture 25, pp. 1$3^{6}$, esp. pp. $3^{-15}$.

37 On the biblical origins of architecture and the allegorical translation of the City Hall via Rome, see Pieter Vlaardingebroek, De geschiedenis van het stadhuis van Amsterdam (Zwolle: WBooks, 2011). On the City Hall as a baroque building, see Katherine Fremantle, The Baroque Town Hall of Amsterdam (Utrecht: Haentjes, Dekker en Gumbert, 1959). 
(The king of the city, the crown of whom would tempt violence, Chose the Tarpeius mountain alone, out of seven, Nearby the stream of the Tiber, and its whirling, Where the eagle and chair of the battle ready people Could be planted as on the free citadel of the commonwealth That would turn against all the powers of the world. Thus the Capitol arose, on this stony rock, Covered by Romulus with a thatched roof, later in gold Like a golden mountain, that, with the setting And rising of the sun, would outshine the sun in pride, An honor for which the mountain thanks Numa As long as the Roman domain, that will never perish nor collapse Will in his own way last, and will stay in this world forever.) translation mine, FWK

Just as Rome was built near the Tiber, Amsterdam was built near the waters of the whirling IJ, and just as Rome had started out with 'thatched roof', so Amsterdam had its humble beginnings. Yet both now had roofs of gold that would shine forever, the one's radiance facilitating that of the other, insinuating that the empire of Rome had now been allegorically transferred to that of Amsterdam. It all followed the logic of the medieval concept of the translatio imperii, according to which history followed the lineage of successive empires.

That said, the legacy of Rome that Vondel used in his poem allowed diverging interpretations. Classical Rome and the Roman Catholic Church could, ambiguously, be mentioned in one breath, as happens in the last line of the cited passage: the political legacy of Rome translates a historically anchored power to a spiritual power that will last eternally in the shape of the Roman Catholic Church — at least in the eyes of Vondel. A less obvious ambiguity, but one that is in play nevertheless, consists of Rome's republican origins, which allows the parallel to unfold more appropriately for a commonwealth of free citizens, and decidedly not an imperial power. At the same time, however, it is the imperial power to rule the world that makes Rome comparable with Amsterdam. The ambiguities in play and the specific form of allegory that they produce by means of which two historical periods are anachronistically conflated while time, simultaneously, is expanding towards eternity, is all distinctly Baroque, but with a twist.

When the City Hall was completed in 1655 the Republic was in its first socalled stadholderless period (lasting from 1650 to 1672 ). Only a decade earlier, with Frederick Henry as the major political ruler, the Dutch politico-aesthetic dynamic had been comparable to other European, royally inspired forms of 
Baroque (although this had been complicated by the fact that Frederick Henry was not a real king, of course). In the seventeen fifties and sixties, in a nonroyal context, the Dutch Republic found itself to be a world power without a real political centre. It was not a straightforward republic, but edged closer to a commonwealth or a confederation, consisting of free and independent states with free people in free cities, and with Amsterdam as city-state that formed both the hub of world trade and of the network of cities. In this context, the Rome-allegory was useful in underpinning the authority of republican forms of statehood because these forms resembled Rome's republicanism and linked Amsterdam's position to that of a former world power. Yet it was a troubling allegory nonetheless, especially in its connection to the Roman Catholic Church, which for many Protestants was equated with tyranny. As for tyranny, yet another historical allegory depicted Rome as the very enemy of the Dutch. This involved the so-called Batavian myth, activated by, amongst others, Hugo Grotius, P.C. Hooft and Vondel, according to whom the free Dutch Republic had its origins sixteen hundred years earlier in a revolt of the Batavian people against Rome's imperial and perverted powers. ${ }^{38}$

The complexities revolving around the Rome-Amsterdam parallel are captured nicely, albeit paradoxically, in a deliberately destroyed manuscript of a tragic play. In a letter to Hugo Grotius dated September 9th, 1639 Joost van den Vondel wrote his friend about the situation he was in and mentioned some of the manuscripts he was sending along or was intending to send:

Ick ben aen de treurspelen vervallen en heb noch éen ongedruckt leggen van Silius en Messaline, en éen ten halven voldaen van Sauls zeven zonen, die bij die van Gabaon opgehangen werden.

(I have been falling back on tragedies and have an unprinted one about Silius and Messalina, and one half finished about Saul's seven sons, who were hanged near Gabaon [...]. $)^{39}$

38 Primary texts, but certainly not the only ones, were Grotius's De antiquitate reipublicae Batavicae from 1610, the play Baeto by P.C. Hooft from 1617 and, much later, Vondel's Batavische gebroeders (Batavian Brethren) from 1662. See Hugo Grotius, The Antiquity of the Batavian Republic, with the notes by Petrus Scriverius, ed. and transl. Jan Waszink et al. (Assen: Van Gorcum, 200o) Bibliotheca Latinitatis Novae; P.C. Hooft, Baeto, ed. Fokke Veenstra (The Hague: Martinus Nijhoff, 1980); Joost van den Vondel, Batavische gebroeders ofte onderdruckte vryheit, in J.F.M. Sterck, et al. (eds), De werken van Vondel. Negende deel 1660-1663 (Amsterdam: De Maatschappij voor goede en goedkoope lectuur, 1936), pp. 898971.

39 Grotius, Briefwisseling, vol. 10, ed. B.L. Meulenbroek. (Martinus Nijhoff, Den Haag, 1976), 
The 'half finished play about Saul's seven sons' was Gebroeders (Brethren), which was published in 1640 , and which became one of Vondel's more successful biblical plays. The other one dealt with Roman material: Silius and Messalina. Sometime after writing this letter, this play apparently had attracted enough funding, for it was being prepared for production. Vondel arranged a first reading of the text together with the actors. During the session, however, one of the actors asked for a clarification of the play's theme and plot: Messalina, member of the vast Julio-Claudian 'family', who had already played a lively role in the entourage of emperor Caligula, now has become the beautiful, powerful, sexually active wife of emperor Claudius, who is physically handicapped and relatively old. She has an affair with the handsome and powerful young Roman senator Silius. When Claudius is away for business she holds a party at which her marriage to Silius, either seriously or mockingly, is arranged. The emperor returns just in time and has her killed, along with Silius and all those present at the party, condemning Messalina to be entirely forgotten, the so-called damnatio memoriae.

Sixteen hundred years later Messalina had not been forgotten, clearly, and Vondel thought her story to be of interest. The actors asked: 'But how should we understand this?' Vondel's biographer Geeraerdt Brandt describes, in a mixture of indirect and free indirect speech, how Vondel responded:

't is eveneens als of zoodaanig een Prins, - dien hy noemde, een nar was, en de Prinses, terwyl hy ergens naar toe was gereist, ondertusschen met een' Raadtsheer wilde trouwen. ${ }^{40}$

(It was just as if a Prince, whom he named, was a fool, and the Princess, while he had travelled someplace else, wanted to marry a counselor in the meantime.)

Obviously, the Prince that Vondel alluded to was Frederick Henry, and the Princess therefore had to be the powerful Amalia van Solms. Although the comparison was met with laughter at first, the actors went to the pub afterwards

p. 582. See <www.grotius.huygens.knaw.nl>. See also: Geeraerdt Brandt, 'Het leven van Joost van den Vondel', in J.V. Vondels Poëzy of Verscheide Gedichten. Op een nieu by een vergadert, en met veele ook voorheen nooit gedrukte dichten vermeerdert: Mitsgaders een aanleidinge ter Nederduitsche Dichtkunste, en het Leven des Dichters (Franeker: Leonard Strik, 1682), pp. 37-38.

40 Geeraerdt Brandt, 'Het leven van Joost van den Vondel', pp. 42-43; translation mine, FWK. 
and started to wonder whether the play was actually an allegory after all. Frederick was indeed frequently away and suffered from severe bouts of gout, and Amalia, well ... ${ }^{41}$ Rumor spread. The regents of the orphanage who had paid for the play were alarmed and Vondel had to act quickly. He went back to the main actors and asked for the manuscripts, with the excuse that he wanted to change a few small things, and thereby preventing illegal prints. He then destroyed the manuscripts, although some parts would be recycled in other work.

Still, there may be much more than a trace of the play left. According to art historian Kees Schoemaker, one painting in the Rijksmuseum made by Nicolaus Knüpfer depicts a scene from the play. Formerly entitled 'Brothelscene', Schoemaker suggests, as a more fitting title, 'Theatrical Scene from Messalina and Gaius Silius Representing the Marriage'.

Schoemaker dates the painting between 1645 and 1655 . As Schoemaker reads it, this is the scene where the party is at its climax, with the half-naked Messalina and Silius toasting, while some of the party guests are already looking outside because someone appears to be rapidly approaching: Claudius. ${ }^{42}$

Whereas a brothel scene could have been read iconographically as a moral warning, the painting would work radically differently if it depicted a scene from Vondel's Messalina and Silius, for then it could possibly be allegorically referring to the stadholder (who died in 1647) and his wife, bringing up the delicate idea of bigamy. The way in which either the play or the painting worked allegorically would depend entirely, obviously, on how one thinks about allegory. For Benjamin, in his dealing with the German Trauerspiel, allegory was a matter of fragmentation, or of allegory artificially referring to itself. By contrast, in the Republic, in relation to this tragedy and in the context of the ambiguities concerning the Roman paradigm, allegory came to act dramatically, as if the cloth of history had been tied into a knot, allowing for Messalina to morph into

41 Ibid., p. 43: 'Om deeze onderrechting en gelykenis werdt in 't eerst gelacchen: maar daarna begosten eenige domme en losse Tooneelspeelers in hunne drinkgelaagen tegens elkanderen te zeggen, zou dit spel wel op dien Prins slaan? Misschien is Claudius die Prins, Messallina zyn Prinses en Silius zulk een Heer, dien zy, (onder andre Grooten, die de gemelde Prinses op de reize naar zeekre stadt verzelden) dwaasselyk uitkipten. Deeze praat liep eerst onder de speelers en werdt, zoo ongerymt als ze was, door zommigen, die den Poëet niet gunstig waaren, verder uitgestrooit, tot dat ze den Regenten van 't Weeshuis ter ooren quam.'

42 Kees Schoemaker, 'Het huwelijk van Messalina en Gaius Silius, ofwel bigamie in het oude Rome, geschilderd door Nicolaus Knüpfer', Bulletin van het Rijksmuseum, $5^{2}$ (2004), 173176. 


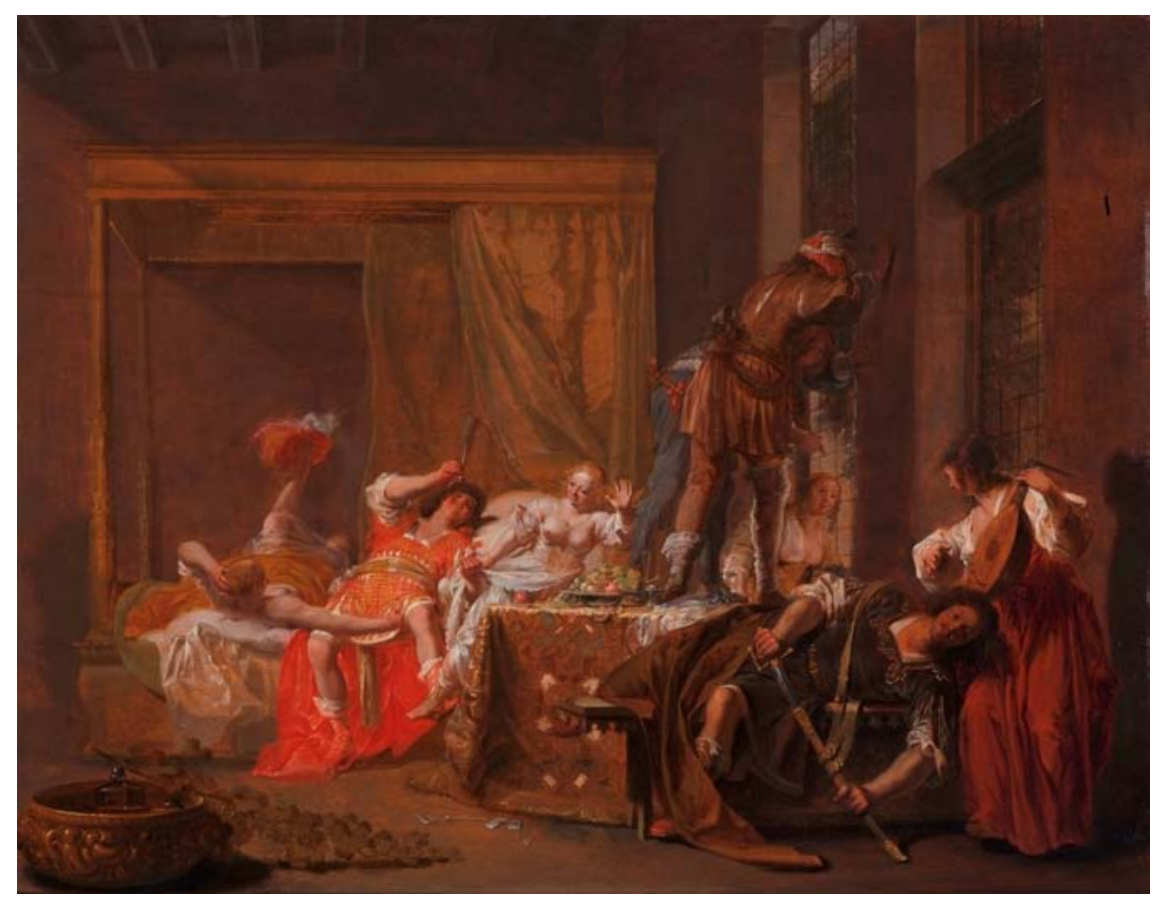

FIGURE 1.1 Nicolaus Knüpfer, 'Brothelscene' or 'Theatrical Scene from Messalina and Gaius Silius Representing the Marriage' (ca. 1645-ca. 1655) RIJKSMUSEUM, AMSTERDAM

Amalia, and the physically ill-disposed Claudius to morph into the physically equally ill-disposed Frederick Henry. ${ }^{43}$ As a result, the theatrical scene became dramatic in a double sense. It was part of a dramatic performance (whether in reality or in a manuscript), and it used two histories that were not so much to be looked at theatrically from a historical distance, but that were operative simultaneously, in the present, fusing into one another.

The force of drama is not so much related to choice, here, but to a double meaning that, because it is folded into one image, produces a confusion that intensifies its political potential. Affectively and aesthetically this is not the intertextual play as it has been defined for the renaissance by Daniel Arasse in Anachroniques and even more so by Alexander Nagel and Christopher S. Wood

43 On Frederick Henry in the last phase of his life, see J.J. Poelhekke, Frederik-Hendrik, Prins van Oranje. Een biografisch drieluik (Zutphen: De Walburg Pers, 1978), pp. 541-564. Poelhekke suggests that his last chapter should have been entitled 'Aftakeling', that is: 'Subsiding', p. 541. 
in Anachronic Renaissance. ${ }^{44}$ To them an anachronistic intertextual concatenation threatened the linearity of history, or the historicity of the work of art, which dissolved in the simultaneous or 'momentous' presence of two historically different times in one painting. In the baroque case, however, the danger does not lie in historically comparing Amalia to Messalina, or in letting the two coincide anachronistically. In the seventeenth century context, this could simply be a matter of laughter and farce bordering on the obscene in a way that would have been familiar to many members of the Dutch elite. On the contrary, the danger lay in the dramatic potential of confusing Amalia with Messalina, and one should note how similar the names sound. The confusing conflation of the two distinct characters, Amalia and Messalina, worked politically as a dramatic interruption that provoked the question in what sense the Dutch Republic resembled a perverted imperial power, in which the commonweal of free people would come to be ruled by something like a JulioClaudian dynasty, in the manner of ancient Rome, one that would rule the state, by implication, as its 'house', with all sorts of perversity as a consequence.

Yet, again, in the case of Vondel, the confusing complexity is also that the Roman paradigm not only works allegorically in relation to the political organization of the Republic, but also in relation to its religious constituency, with Rome indicating the Roman Catholic Church that, as the former universal house of the father, was now opposed by other religious powers. Indeed, in the context of the Dutch Republic the question was what kind of political household the Protestant church had become after the Reformation. Aside from that question, there was also, as we just saw, another political house involved: the house of Nassau.

\section{The Quasi-Royal and Counter-Remonstrant Household of the State-and a Baroque Response}

Interviewed in 2009 on the occasion of the republication of three of his studies on the Golden Age, historian A.Th. van Deursen stated that the Netherlands even today remains 'rooted in seventeenth-century religion'. With respect to this, he expressed his concern about the fact that so few people could understand nowadays that to the seventeenth-century mind, belief was 'a public

44 Daniel Arasse, Anachroniques (Paris: Gallimard, 2006); Alexander Nagel and Christopher S. Wood, Anachronic Renaissance (New York: Zone Books, 2010). 
affair'.45 In the introduction to his study Bavianen en Slijkgeuzen Van Deursen had already stated that seventeenth-century Protestants did not much speak of the Protestant church. Instead they would speak:

[...] often about the Christian reformed religion. Not a coincidence, for sure; people did not want to see the existing domestic church organization as an enclosed national institute [...] but as the local materialization of a much bigger unity ${ }^{46}$

Although there is much with which one can agree here, the danger is that Van Deursen mistakes the conceptual pair 'private' and 'public' for the political spaces of dominium and the res publica. As I suggested in the previous section, the basic political and juridical problem that plagued European politics was the superimposition of dominium over public affairs, an issue addressed by consecutive political thinkers such as Marsilius of Padua and Machiavelli, or much later Hannah Arendt. As I have already mentioned, as early as the fourteenth century Marsilius of Padua had argued, in his Defensor Pacis, that the Roman Catholic Church was an oixos, a house, which as such should not be allowed to lay claim to the public space of politics. Of course laying such a claim was exactly what the Church did. For this very reason, Marsilius argued, it acted illegitimately. Likewise the issue of debate in the seventeenth century was not whether belief was a public matter or not, it was whether any church could lay claim to public affairs from the position of an oikos or dominium, as was clearly the case with the Counter-Remonstrants.

In the same interview Van Deursen repeats the argument that he developed in his study on stadholder Maurits: Maurits van Nassau: De winnaar die faalde (Maurits of Nassau: The Winner who Failed, 2001). The book's thesis is that, despite Maurits's position as one of Europe's great military leaders, his ultimate failure consisted in how he dealt with Van Oldenbarnevelt. Maurits got him beheaded for political reasons_-reasons that Van Deursen finds indefensi-

45 Geertje Dekkers, 'A.Th. van Deursen over “De Gouden Eeuw compleet”, , Historisch Nieuwsblad 10 (2009).

46 A.Th. van Deursen, Bavianen en Slijkgeuzen, p. 1: 'Wie vertrouwd is met de vroege zeventiende-eeuwers, weet dat ze weinig spreken van de hervormde of de gereformeerde kerk, maar veel van de christelijke gereformeerde religie. Geen toeval zeker; men wilde de binnenslands bestaande kerkelijke organisatie niet zien als een besloten nationaal instituut, als een op zich zelf staande grootheid, maar als de locale verschijningsvorm van een veel groter geheel.' 
ble. The basis of the political conflict had not been, according to Van Deursen, that Maurits had sided with the Counter-Remonstrant and Oldenbarnevelt with the Arminians. Rather, both had a fundamental difference of opinion about the nature of the relation between state and religion. Oldenbarnevelt considered the state a political power that could guarantee different forms of religion existing peacefully next to one another; Maurits, on the other hand, considered orthodox Calvinism the one church that could guarantee the safety and coherence of the state. It is remarkable, here, that Van Deursen only mentions one 'house', as when he considers how Maurits's political maneuvering can be explained on the basis of his concern for the house of Nassau. This house is symbolically and metonymically the embodiment of a state with one religion, one that for Maurits and Calvinists was the 'essential characteristic of that state' as Van Deursen defined it. As we already saw, Van Deursen did not consider this religion in terms of a 'household'. Perhaps, spiritually speaking, it was not. Ideologically, however, and in the judicial and daily praxis of the Dutch Republic, it definitely was. After the Synod of Dordt, the Counter-Remonstrant strategy was to get the household of church and state, considered to be one, unified in good order. To that aim torture was used, as is understandable, considering the intrinsic historical link between dominium and torture.

All things considered it might seem strange, or slightly paradoxical, that Grevius contends, in his treatise, that torture should be principally impossible for Christians. To be able to appeal to Christianity as the stronghold against torture, he refrained from basing his argument on the history of positive law which had influenced the development of European law since the revival of Roman law in the Middle Ages. Grevius first addressed some of the arguments that people might bring in to defend torture as being understandable and somehow reasonable, and then argued that a law that contradicted reason could be no law at all. Such reasonability could not be based on custom or posited law. Grevius used either divine law or natural law (like Grotius would) as the source of reason, much like Thomas Aquinas had contended. The point was expressed succinctly by an 'or': 'naturae lege aut divino iure'. By bringing in divine law or natural law, Grevius held that there is no law above these. Considered on its own, the appeal to natural law, moreover, implied the Althusian notion that each man is sovereign, that is free, by nature. ${ }^{47}$ The very notion of man as sovereign was a horror, however, to Counter-Remonstrants, or to most royalists for that matter, such as Filmer for instance. 
The 'tuchthuis' where Grevius was imprisoned had been installed in 1596. In general, the prisons that would be built throughout Europe in the centuries to come would contribute considerably to the disappearance of juridically backed up forms of torture. ${ }^{48}$ Yet while the establishment of the Amsterdam 'tuchthuis' indeed offered an alternative way of punishment in the long run, in the hectic years after 1618 torture was used regularly. If it is the case, as Elisabeth Lissenberg suggested, in her preface to a study on the early modern prison system in Europe by Pieter Spierenburg, that the way in which states dealt with criminals in the Republic was 'part of a larger social process in which justice from above grew stronger in connection with the increased power and confidence of the state authorities', one would have to be very clear what sort of a political 'above' this might be, and what kind of state authorities were so confident about their powers. ${ }^{49}$ The severity of the judicial processes and punishments after 1618 was distinctly religio-political, especially with Reinier Pauw as the dominant political player in Amsterdam (acting as burgomaster in 1605, 1609, 1611, 1614, 1616, 1617, 1619 en 1620). Due to his being a staunch proponent of the Counter-Remonstrant party, he was appointed to sit in the council that judged Oldenbarnevelt, and condemned him to death. Moreover, in the context of the 'wetsverzetting' of 1618 he had helped cleanse the Amsterdam city council from its major Remonstrant figures. However, from 1621 onwards - the year of Sapma's, Prince's and Grevius's escape from prison - the moderate forces regained most of their strength, which led to the resurfacing of the political ideas of Oldenbarnevelt, Grotius and their likes. Consequently, policies were defined much less in terms of dominium, in the sense of a fusion of a house based political rule with a religious one, as Maurits and the Counter-Remonstrants desired. Instead the cities, the states, and the States-General were considered more and more in terms of as a public affair, in the sense of a res publica.

In the context of a prosperous Republic that was indeed concerned with the res publica, torture did not disappear from one moment to the other. It did become less and less acceptable, however, losing its aura of legitimacy. The Dutch Republic was, and was not, a particular case in Europe. As Clive Emsley has argued, it was only after $175^{\circ}$ that princes and sovereigns throughout Europe started reforming the juridical system which was founded on the Constitutio Criminalis Carolina from 1530 , a document which had led to many witch

48 On the Amsterdam 'tuchthuis' in its European context see Pieter Spierenburg, The Prison Experience; Disciplining Institutions and their Inmates in Early Modern Europe (Amsterdam: Amsterdam University Press, 2007).

49 Elisabeth Lissenberg, 'Preface' to Spierenburg, The Prison Experience, p. 1. 
trials and torture practices in the two centuries to follow. ${ }^{50}$ In the light of this information the Dutch Republic was distinctly ahead of its time. Yet according to John Langbein torture was on the way out generally in Europe from the early seventeenth century onwards, not so much due to passionate humanist pleas such as Grevius's but due to 'the development of new criminal sanctions and the revolution in the law of proof'. ${ }^{51}$ Accordingly, Lisa Silverman in her study of torture in Early Modern France can state:

My evidence, like that of other historians, demonstrates a dramatic decline in the employment of torture from the beginning of the seventeenth century. But my evidence also shows a continued employment of torture $[\ldots] .52$

As Silverman continues to explain, and in line with Langbein's analysis, it was not so much because of legal requirements that torture was still employed but 'because it had a powerful cultural significance'. 53

As for this cultural significance, it is telling that torture was made fun of in the Dutch Republic. A text that may prove this point is Jan Vos's play Aran en Titus of Wraak en weerwraak: treurspel (Aran and Titus: Revenge and Revenge in Retaliation: A Tragedy; 1641). In general it might seem a tragic play but it might equally well be distinctly comical, as a result of which the theme of torture is dealt with irreverently. This becomes most explicit at the end of the play. Notably, this happens again in relation to the theme of Rome and its perverse power games. It is not sure whether Vondel really liked Vos's dealing with the issue, or the latter's form of tragedy per se. In a letter from Barlaeus to Huygens, the former describes his own response, and the reaction of Hooft, Van der Burg and Vondel. The latter's response to the play is described as follows:

50 Clive Emsley, Crime, Police and Penal Policy: European Experiences 1750-1940 (Oxford: Oxford University Press, 2007), especially the chapter 'Laws and Punishments'.

51 John Langbein, Torture and the Law of Proof: Europe and England in the Ancien régime, (Chicago: The University of Chicago Press, 1977); or 'Torture and Plea Bargaining', The University of Chicago Law Review, 46 (1978), 3-22. See also Edward Peters, Torture (Philadelphia: University of Pennsylvania Press, 1996).

$5^{2}$ Lisa Silverman, Tortured Subjects: Pain, Truth and the Body in Early Modern France (Chicago: University of Chicago Press, 2001), p. 24. Silverman's findings are in line with Peter Paalvast, Martelen en martelwerktuigen in cultuurhistorisch perspectief (Zoetermeer: Free Musketeers, 2011).

Silverman, Tortured Subjects, p. 24. 
Audivit Vondelius, et portentosi ingenij virum dixit. ${ }^{54}$

The editors translated this as 'Vondel heeft het gehoort, en zeide, 't is een man van wonderbaer verstandt' ('Vondel has heard it and said it was a man of miraculous wit'). Yet the choice of words, especially 'portentosi' may be more delicate since the same word may indicate 'unnatural', 'miscreant' or 'fantastic'.

Whether or not Vos had read Shakespeare, his play is a clear intertextual allusion to or reworking of Shakespeare's Titus Andronicus. ${ }^{55}$ It is, moreover, an almost bizarre mixture of formal classicist requirements (like the unity of time, the division in acts, the use of alexandrines) and baroque (like the excessive show of violence, the many unexpected turns in the plot, the extravagance of emotions). ${ }^{56}$ The actors on stage at the end of the play-we have lost more than a few-are Saturninus, the emperor, and his wife Thamera, who has been queen of the Goths and lover of Aran but who, in order to save the latter's life, has agreed to marry the emperor. Then there is Titus Andronicus, a general, with his brother Markus and son Lucius. And finally there is Aran, the black leader of the Goths who has succeeded in getting his revenge on the Romans, by killing the emperor's brother. Thamera has just learned that Titus, who organized a diner, has given her her own children to eat. In rage she has cried out for Aran, who was captured earlier but now suddenly bursts on stage through a 'loose Soldering': a trapdoor. ${ }^{57}$

The illustration of the scene in the 1648 edition is a marvelous example of epic condensation since we simultaneously see Aran hanging above the fire and the sharpened spikes, while Titus is stabbing Thamera and Lucius slaying Saturninus. All this does not happen simultaneously, however, for this is how the play ends:

54 Constantijn Huygens, Briefwisseling, vol. 3: 1640-1644, ed. J.A. Worp (Martinus Nijhoff: Den Haag, 1914); <http://www.dbnl.org/tekst/huygooijawoo5_01/huygooijawoo5_01_0630 .php>.

55 On this see Jan Vos, Toneelwerken, ed. W.J.C. Buitendijk (Assen and Amsterdam: Van Gorcum, 1975), p. 53 and 64, but more extensively Willy L. Braekman, 'The relationship of Shakespeare's Titus Andronicus to the German play of 1620 and to Jan Vos's play Aran en Titus', in Studia Germanica Gandensia 10 (Gent 1968), 7-77. See also the contribution by Helmer Helmers in this volume.

56 On this see Buitendijk in his introduction to Jan Vos, Toneelwerken, p. 59 and pp. 68-72.

57 Jan Vos, Toneelwerken, p. 208. 


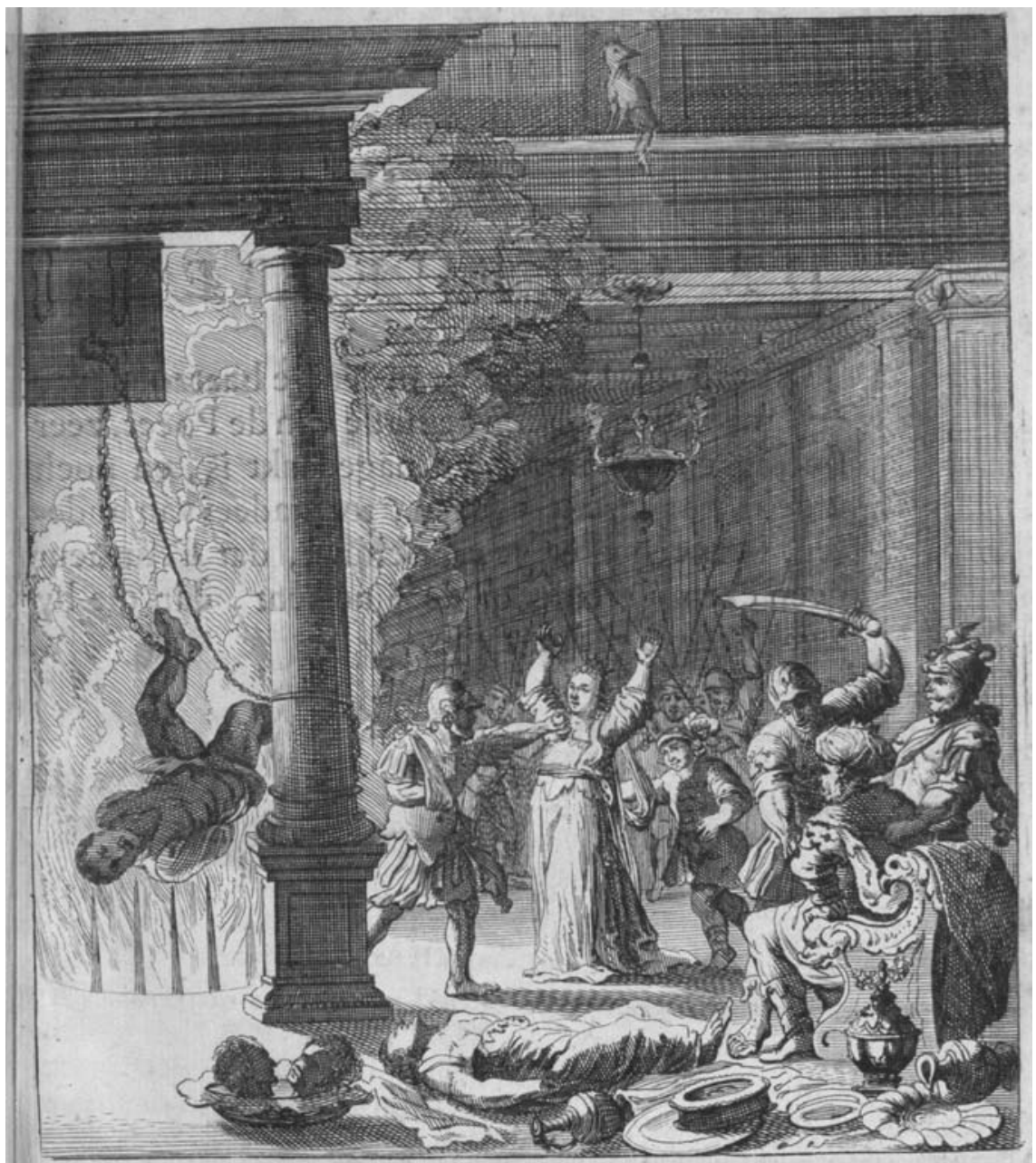

FIGURE 1.2 Illustration VII from Jan Vos, Aran en Titus (ed. 1648)

SATURNINUS Hoe zal ik Broeders doodt, hoe zal ik't schelmstuk wreeken?

Wie zal my bystandt doen?

TITUS Ik zal u hulpzaam zijn.

ARAN

O ysselijke val! o doodelijke pijn!

Help Titus! Titus help! ik zal uw gramschap kussen.

TITUS

De wraak keert u de nek.

ARAN

Wie zal deez' vlammen blussen?

TITUS

De traanen van uw' hoer.

ARAN

Genâ! genâ! genâ! 
TITUS

ARAN

TITUS

ARAN

TITUS

ARAN

TITUS

ARAN

TITUS

TITUS

SATURNINUS:

LUCIUS

MARKUS
Als 't quaaddoen wordt gestraft, dan komt 't berouw te spâ.

O Titus! geef genâ.

De wraaklust heeft geen ooren.

Bepaal de woede wraak van uw' getergde tooren. Hadt gy u wreede handt, in al uw' doen, bepaalt.

De weerwraak was zoo fel niet op uw' hooft gedaalt.

Hier leit hy in zijn graf die ons in 't graf wou wikkelen.

O overheete vlam! o al te scherpe prikkelen!

Kom Titus, Titus kom, en kerf mijn leevens draân.

Eerst moet het rauwe vleesch tot op het been toe braân.

Help spooken! spooken help! ik ben om hulp verlegen.

Stort dolle donderaar, stort nu een dichte regen,

Met uw' vergramde vuist, van blixems op my neêr;

Op dat ik, in der yl, tot assche toe, verteer.

$\mathrm{O}$ wee! o wee! o wee!

De schelm is al gezonken;

Hy leit, als in de gloedt van Ætnas bergspelonken.

SATURNINUS $\mathrm{Nu}$ is mijn wraak vernoegt: mijn broeders geest gepait;

Ik zwem in ene zee van alle dartelheidt

Het hart springt me van vreugdt.

Ik zal de vreugdt betoomen.

Daar moorehoer, hou daar; gy zult uw' pol bekoomen

In 't onderaardsche Rijk.

Hou daar vervloekte guit,

En volg de bloedge schreên van Saturninus bruidt.

Is vaader doodt? o doodt! door Saturninus handen?

Tyran daar is uw' loon.

Uw' Kaizerlijke banden

Zijn nu voor Lucius, en wat aan 't Rijk behoort.

$\mathrm{Nu}$ zal het noodig zijn, dat gy des Tybers poort,

En 't ruime marriktveldt, omheinigt met uw' troepen,

Dan zalmen 's Vorsten doodt, en u voor Vorst, uitroepen;

En wie'er teegens streeft, alwaar 't de Ridderschap,

Zal voort naar Pontus Meir, in eeuwge ballingschap.

Aran en Titus, ll. 2092-2126

(SATURNINUS How shall I avenge my brother's death, this villainous act?

And who will assist me? 
TITUS

ARAN

TITUS

ARAN

TITUS

ARAN

TITUS

ARAN

TITUS

ARAN

TITUS

ARAN

TITUS

ARAN

TITUS

SATURNINUS
I will help a hand. (Opens trapdoor that drops Aran into a fire, hanging above a set of sharpened spikes.)

Oh chilling fall, oh deadly pain!

Help Titus, Titus help! I will kiss your wrath.

Revenge shows you its neck.

Who will extinguish these flames?

The tears of your whore.

Mercy! Mercy! Mercy!

If evil acts are punished, then remorse comes too late.

Oh Titus, show mercy!

Revenge does not have ears.

Restrict the raving revenge of your incited anger.

If you had restricted your cruel hand in every act

Revenge in response had not come down on your head so fiercely.

Here lies in his grave who would have liked to wrap us in ours.

Oh overheated flames! Oh all too sharpened skewers.

Come Titus, Titus come, en splice my life on them.

First the raw flesh must be baked to the bone.

Help, ghosts! Ghosts help! I am in dire need of assistance.

Pour down, mad thunderer, pour down a vast rain

Or with your wrathful fist, lightnings, down on me,

So that I, in a split second, will perish to ashes.

Vie! Vie! Vie!

The villain has gone down already.

He lies as in the glowing embers of Etna's mountain caverns.

Now my revenge has been fulfilled; my brother's spirit satisfied.

I am swimming in a sea full of exhilaration.

My heart bursts out from joy.

I will restrain the joy. (Slays Thamera.)

There, black man's whore, have it, you will get your butt friend

In the empire of hell.

SATURNINUS (seeing his wife slain, slays Titus) There you have it, damned scoundrel,

And now follow the bloody steps of Saturninus's bride. 
LUCIUS Is father dead? Oh dead! By Saturninus's hands? Tyrant, here is what you deserve! (Slays Saturninus.)

MARKUS Your imperial headscarves

Are for Lucius now and what belongs to the empire.

Now it will be required that the Tyber's gate

And the spacious market field will be surrounded by your armies.

They will proclaim the monarch dead and you monarch And all those who will oppose it, be they aristocrats, Will be off to the Black Sea, in eternal exile. $)^{58}$

There is much that is farcical in this passage, or bordering on the obscene. It starts with a hilarious 'ijsselijke' or 'chilling' fall in a fire; proceeds with the one who is tortured in the fire asking who will extinguish it; which is then followed by the response that it can only be extinguished by the tears of the 'whore' of the one tortured. Then there is the threefold lyrical repetition by the one who is being roasted: 'Help Titus! Titus help!', 'Come Titus, Titus come', 'Help ghosts! Ghosts help!'; or the dry funeral epitaph of 'Here lies [...]'. Those who have pictured the Etna, with its lethal glowing lava, will have pictured the sea as well on which it borders, hence Saturninus's sea of joy. There is a double pun on 'pol', which can either mean slut or faggot. Finally, after the rapid and gory death of four characters, the play ends in a business-like tone, in a concluding line that expresses the amoral or brutish nature of Rome's imperial power politics.

Funny, thrilling, horrific or sublime as it is, the play fits in the context of a multifaceted resonance between Rome and the Dutch Republic that in several cases, and in different media, allowed for a consideration of torture as a sign of the perversity of Roman power. A decade after the first performance of Aran en Titus, for instance, the Dutch translation of Grevius's treatise was published in Rotterdam, written by the physician and writer Daniel Jonctys, entitled $D e$ pyn-bank wedersproken en bematigt (Argument Against the Rack in Favor of its Moderate Usage). With the Dutch Republic's turning away from or tempering the powers that had preferred dominium based politics, torture was on the way out as well, as the reprints of the text suggest (in 1651, 1736 and 1740) and a Latin version based on the earlier Dutch one in 1653 (De torturae abusu et necessaria moderatione, Dordrecht), or again a pamphlet-like summary in 1690 (Rotterdam). To be sure, as may be clear also from the dates of the reprints,

$5^{8}$ Jan Vos, Toneelwerken, ed. Buitendijk, pp. 208-210. 
this did not happen overnight. In fact it would take until 1798 until torture was officially abolished, and a century earlier, during the second stadholderless period that Johan de Witt would call the period of 'The True Freedom', torture was still used. The point is that although it would take time, torture became less and less accepted and consequently a dominium based kind of law had to be reconfigured.

During this process, baroque art in the Dutch Republic was not so much fascinated by torture per se but by the perverse power structures that facilitated it. Or, the issue of torture was embedded in and framed by a distinctly Roman heritage - in terms of jurisdiction, politics and aesthetics - that got a specific reception in the Dutch Republic. This is what connects Vondel's destroyed tragedy on Messalina and Silius with Vos's surviving one on Aran and Titus. The political perversion that is central to both plays concerns the fusion between dominium and imperium, and this perversion was something that almost unexpectedly confronted those who were culturally reworking the Roman material in the Dutch Republic with, in the end, incompatible or paradoxical material. It is this incompatibility, the fragmented or paradoxical nature of the relation between the Republic and Rome, that makes it baroque. ${ }^{59}$

\section{Further Reading}

Frankenberg, Gunter, “Torture and Taboo: An Essay Comparing Paradigms of Organized Cruelty', The American Journal of Comparative Law 56 (2008), pp. 403-422.

Nyquist, Mary, Arbitrary Rule:Slavery, Tyranny and the Power ofLife and Death (Chicago:

Chicago University Press, 2013).

Weststeijn, Thijs, Art and Antiquity in the Netherlands and Britain: The Vernacular Arcadia of Franciscus Junius (1591-1677) (Leiden and Boston: Brill, 2015).

59 I would like to thank the editors, as well as Marijn van Dijk, Helmer Helmers, and Marrigje Paijmans for their valuable comments. 